UDC 613.15

DOI: 10.21668/health.risk/2018.1.05.eng

\title{
INFLUENCE EXERTED BY NATURAL-CLIMATIC CONDITIONS ON AIR QUALITY ON AREAS WHERE OPEN-AIR SPORT FACILITIES ARE LOCATED (ON THE EXAMPLE OF KAZAN)
}

\author{
N.Kh. Davletova ${ }^{1}$, E.A. Tafeeva ${ }^{2}$ \\ ${ }^{1}$ Povolzhskaya State Academy for Physical Culture, Sport and Tourism, 35 Universiada Viollage, Kazan', \\ 420010, Russian Federation \\ ${ }^{2}$ Kazan State Medical University, 49 Butlerova Str., Kazan', 420012, Russian Federation
}

Atmospheric air contamination holds the first place among priority factors which determine environmental risks for sportsmen's health at open-air sport facilities. Training processes especially those aimed at aerobic endurance development and improvement are inefficient under ecologically unfavorable conditions. Our research goal was to assess atmospheric air quality on territories where open-air sport facilities were located in Kazan. Our initial materials were data on contaminants emissions on Kazan territory, results of instrumental research on air quality, data taken from state Reports on natural resources and environmental protection issued in Tatarstan in 2006-2016.

We examined impacts exerted by meteorological conditions on dispersion and accumulation of emissions from stationary sources and automobile transport in close proximity to open-air sport facilities. We charted all the open-air sport facilities and enterprises and assessed mutual influences by various city districts on each other depending on prevailing winds which determined contaminants transfer from place to place. Our analysis on winds repeatability from May to September over 2006-2016 revealed that North-West wind prevailed in July, and West wind, in May, June, August, and September. Conditions which were favorable for contaminants dispersion were observed only in $30.9 \%$ of months over the examined period; partially favorable or even unfavorable ones occurred in $69.1 \%$ of time. So, natural-climatic conditions existing in Kazan create specific qualitative composition of city air and contaminants are present in atmospheric air above open-air sport facilities in concentrations exceeding maximum permissible ones. It causes potential risks for sportsmen's health. The obtained data give grounds for air monitoring planning at periods when sport events take place; for organizing work at priority enterprises when meteorological conditions are unfavorable; they can also be applied when changes are made into architectural and design plans for the city territory including transport routes development; or when activities aimed at environment protection are developed and implemented.

Key words: atmospheric air, contamination sources, natural climatic conditions, contaminants, open-air sport facilities, sportsmen's health.

Atmospheric air contamination holds the leading place among priority factors causing environmental health risks for sportsmen at open-air sport facilities [1-4]. Breathing speed of a sportsman under maximum loads during 20-30 minutes can reach 100-120 breaths per minute [5]. Such an increase in ventilation is provided by greater breathing frequency and volume, and here frequency can rise to 60-70 breaths per minute, and breathing volume, from 15 to $50 \%$ of the lung vital capacity. As per data taken from various research, training process efficiency under unfavorable environmental conditions is very low. It is especially true in case of a training

(C) Davletova N.Kh., Tafeeva E.A., 2018

Nailya Kh. Davletova - Candidate of Medical Sciences, Associate Professor at Medical-biological Subjects Department (e-mail: davletova0681@mail.ru; tel.: +7 (843) 294-90-86).

Elena A. Tafeeva - Doctor of Medical Sciences, Associate Professor at Hygiene and Occupational Medicine Department (e-mail: tafeeva@mail.ru; tel.: +7 (843) 236-97-02). 
process which is aimed at "aerobic endurance" developing and improving. Unfavorable ecologic conditions don't exert such a drastic impact on training speed and strength physical qualities related to "anaerobic endurance". It is caused by the fact that aerobic capabilities which have been developed in a highly qualified sportsman are a specific reserve for their own selfrecovery [6-8].

Industrial enterprises (stationary) and motor transport (moving) are basic sources causing atmospheric air contamination above open-air sport facilities in a big city [9]. A peculiarity of stationary air sources is that contaminants emitted by them can be distributed over large territories due to emissions mostly occurring at big heights. Moving air contamination sources have their own peculiarities, namely, they are located at the surface (at breathing zone level), they are distributed over territories with boundaries which are hard to define, and they constantly move from place to place.

Kazan, Tatarstan capital city, is a large industrial center. A lot of open-air facilities are located on its territory. Given the fact, that training and competitions first of all involve more frequent breathing, we can assume that contaminants enter a sportsman's body with the atmospheric air in quantities which are always greater than in case of any average statistical person living near an open-air sport facility. Therefore, an issue of air contamination above open-air sport facilities becomes truly vital for Kazan.

Our research goal was to assess atmospheric air quality on territories where open-air sport facilities were located.

Data and methods. We based our analysis of atmospheric air quality in a district where an open-air sport facility was located on data on total contaminants emis- sions; these data were obtained from reports on air quality, social-hygienic monitoring system, State reports on natural resources and environmental protection issued in Tatarstan in 2006-2016.

We examined influence exerted by meteorological conditions on dispersion and accumulation of emissions from stationary sources and motor transport as per data taken from the Kazan city official weather archive $[10,11]$. In particular, we analyzed data on the following values and phenomena: wind speed and direction, temperature inversions and fogs, precipitation during periods from May to September 2006-2016. Applying the above mentioned data, we built wind roses and calculated meteorological coefficient for air selfcleaning. This coefficient was calculated as per a conventional procedure developed by T.S. Selega [12].

Results and discussion. Air contamination above an open-air facility in a large city depends on stationary sources locations, emissions from motor transport, contaminants distribution (movement) around a city (district) area, as well as on natural-climatic conditions.

Along with admixtures concentrations in the air which are always present near specific objects, background air contamination also occurs in a city; it happens due to mutual overlap and mixing of emissions from many sources. In relation to that high toxicants concentrations in the air can occur even on territories which are not directly influenced by specific objects. Background air contamination caused by meteorological conditions can be observed above the whole city during a day; when emissions from enterprises are constant, it can enhance or weaken under weather conditions influence [13, 14].

16 large open-air sport facilities are located in Kazan: 5 objects in Vakhitovsliy 
district; 5, in Privolzhskiy district; 2, in Novo-Savinovskiy district; 2, in Sovetskiy district; 1, in Moskovskiy district; 1, in Aviastroitelniy district. large indutrial enterprises which are stationary air contamination sources are also located in the same districts (Figure 1).

Motor transport makes the greatest contribution into contamination of air above open-air sport facilities in Kazan, its share on average being equal to $70 \%$; other contamination sources are such enterprises as Kazanorhsyntes PLC, Heating plant 1, Heating plant 2, Heating plant 3, Kazenergo, and Kazan reinforced concrete structures plant LLC. Annually about 80.2 thousand tons of contaminants are emitted into air in Kazan by motor transport, and about 30.6 thousand tons, from stationary sources. Contaminants emissions dynamics comprising substances being emitted into the atmosphere in Kazan both from stationary sources and motor transport is shown on Figure 2.

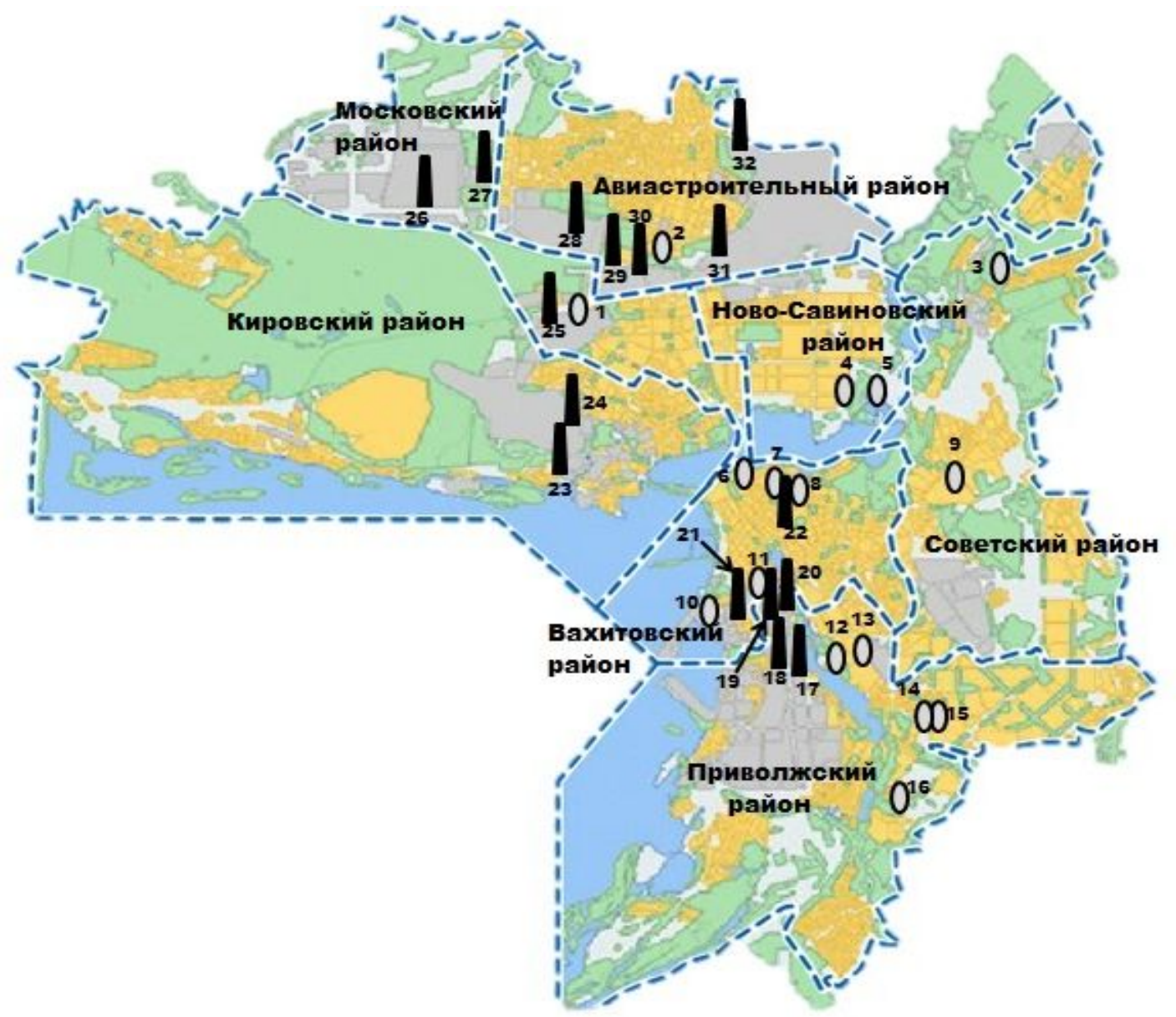

Figure 1. Open-air sport facilities and industrial enterprises location in Kazan 1 is "Tasma" stadium, 2 is "Rubin" stadium, 3 is "Raketa" stadium, 4 is a football stadium at "Olymp" sport complex, 5 is "Kazan-Arena" stadium, 6 is "Centralniy stadium", 7 is "Dinamo" stadium, 8 is "Trudovye reservi" stadium, 9 is "Miras" stadium, 10 is "Vodnik" stadium, 11 is "Electron" stadium, 12 is Rowing center, 13 is "Field hockey center" stadium, 14 are open tennis courts at Tennis Academy, 15 is 'Burevestnik" stadium, 16 is a stadium at s"Tulpar" sport complex, 17 is Heating plant 1, 18 is Kazan medical-instrumental plant, 19 is "Tochmach" Kazan plant, 20 is "Nephis Cosmetics" PLC, 21 is Kazenergo, 22 "Kazan plant Electropribor" PLC, 23 is "Santechpribor" PLC, 24 is State Gunpowder Plant, 25 is Chimgrad, 26 is Heating plant 3, 27 is "Kazanorgsyntes" PLC, 28 is Kazan helicopter plant, 29 is Heating plant 2, 30 is Kazan silicate building panels plant, LLC, 31 is Kazan reinforced concrete structures plant, 32 is Kazan aviation plant. 


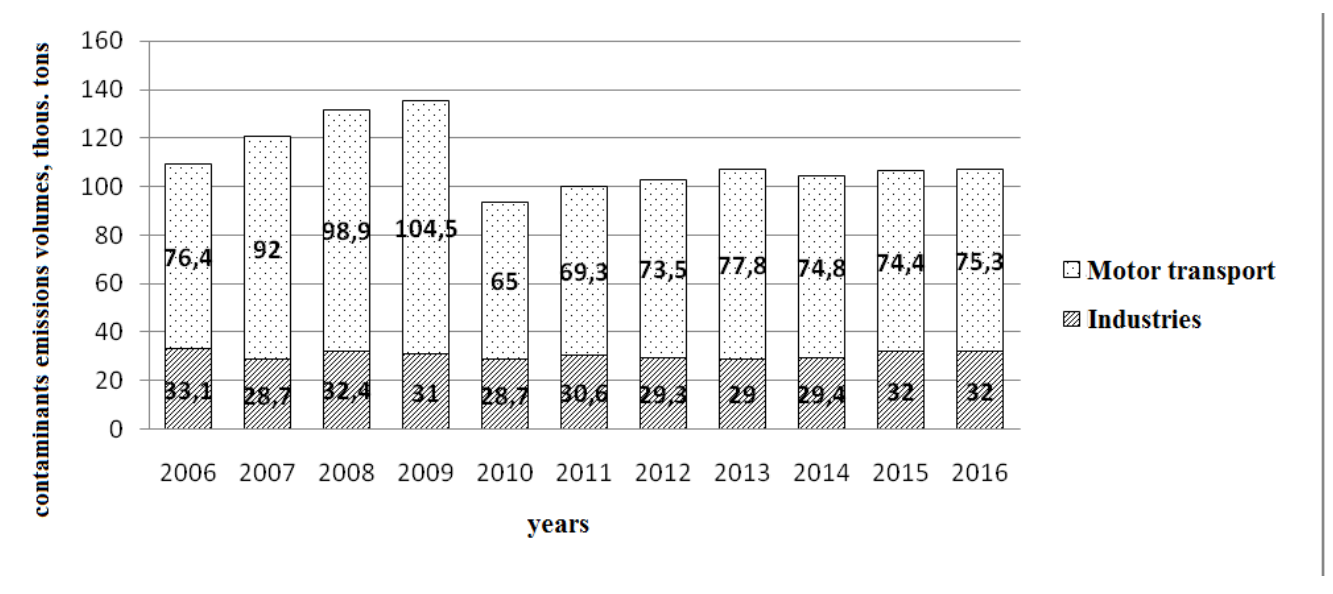

Figure 2. Dynamics of contaminants emissions into the atmosphere in Kazan over 2006-2016.

Gaseous and volatile organic substances, nitrogen oxides, carbon oxide, hydrocarbons, and suspended substances, are basic contaminants which pollute the atmospheric air. At each period from May to September, 2006-2016, on average 695 cases when pollutants concentrations exceeded maximum permissible levels were registered in Kazan, 108 of them being related to suspended substances; 72, to carbon oxide; 244, to nitrogen dioxide; and 113 , to formaldehyde.

The detected excesses cause risks for sportsmen's health. Registered air quality allows us to predict unfavorable impacts on respiratory organs, eyes mucous tunics, as well as specific immune disorders (including allergic reactions evolvement). The highest risks occur for respiratory organs, and it is vital, first of all, for sportsmen who participate in competitions being held at open-air sport facilities in the city. Maximum hazard index (HI) related to respiratory organs is predicted to be equal to 32.8 on Kopyilova street in a zone where a sport complex is located which is 30 times higher than the permissible level. Risk for respiratory organs higher than $10 \mathrm{HI}$ is predicted in a zone close to "Rubin" stadium. 6-7 HI which can be estimated as high risks can occur under certain conditions in a zone where "Electron" stadium is located.

The detected risks of acute inhalation impacts are caused by a set of admixtures, however, basic contributions are made by not more than 10 priority admixtures out of 280 examined at an exposure assessment stage.

We determined that risks for respiratory organs is primarily caused by the following substances: nitrogen oxides, sodium hydroxide, sulfur anhydride, and dusts, including fine-dispersed ones. Contribution made by nitrogen dioxide into hazard indexes varies from $12.9 \%$ to $62.3 \%$ in different locations; nitrogen oxide, from $1.4 \%$ to $12.4 \%$; dusts mixture, from $8 \%$ to $73.7 \%$; sodium hydroxide, from $2.65 \%$ to $26.9 \%$; sulfur dioxide, from $3.6 \%$ to $20.7 \%$; ammonia, from $0.38 \%$ to $6.9 \%$; nitric acid, from $0.59 \%$ to $19.6 \%$. Totally these contaminants cause from $84 \%$ to $97 \%$ acute inhalation impacts risks for respiratory organs in various city districts. Other admixtures contribution doesn't exceed $1 \%$. Share contributions made by priority admixtures change depending on a sport object location; however, priority contaminants remain the same. 
Natural-climatic conditions exert substantial influence on hazardous substances accumulation in the atmosphere. Such factors as weak winds, surface inversions, and calm weather, are well-known to greatly influence hazardous substances distribution in the atmosphere thus determining its capability to clean itself $[2,15]$. A ratio of repeatability of conditions making for admixtures accumulation (weak winds and fogs) to repeatability of conditions which, in their turn, make for admixtures elimination (strong wings and precipitations) is called air self-cleaning coefficient [16].

In our research we calculated air selfcleaning coefficient during a period from May to September, 2006-2016, and detected that the air in the city has partially favorable capability to clean itself from May to August $(\mathrm{C} \mathrm{m}=0.96-1.14)$, and favorable conditions for admixtures dispersion were detected in September (C` $m=1,27)$. Longterm average air self-cleaning coefficient values indicate that partially favorable conditions for admixtures dispersion prevail from May to September (Figure 3).

According to our analysis, favorable conditions for contaminants dispersion were observed only in $30.9 \%$ months over the examined period; in $69.1 \%$, conditions were partially favorable or even unfavorable. Weak winds $(0-1 \mathrm{~m} / \mathrm{sec})$ repeatability makes the greatest contribution into occurrence of unfavorable conditions for air selfcleaning. On average, mild winds (less than $4 \mathrm{~m} / \mathrm{sec}$ ) or even calm weather is observed on $27-30 \%$ days in Kazan [12]. Admixtures accumulation in the atmosphere enhances in case of fog. A number of foggy days varied from 8 to 29 per year on average, and a number of days when conditions for contaminants dispersion were unfavorable, from 58 to 128 per year (Table 1).

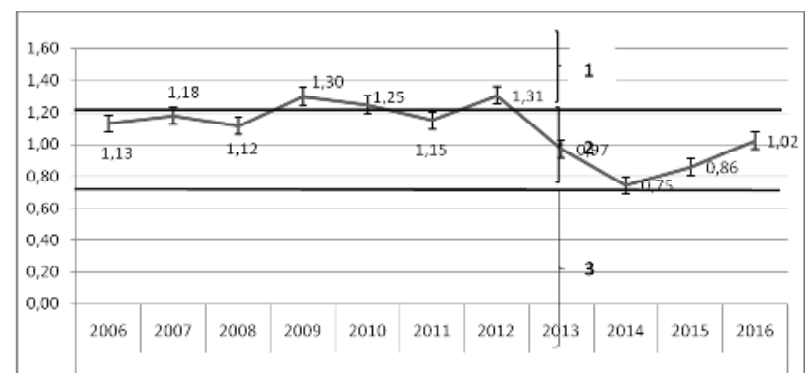

Figure 3. Air self-cleaning coefficient variability over 2006-2016 in Kazan:

$1-\mathrm{C}^{\prime} \mathrm{m}>1,2$ means favorable conditions for air selfcleaning; $2-0.8<\mathrm{C}^{\prime} \mathrm{m}<1,2$ means partially favorable conditions for dispersion; $3-\mathrm{C}^{\prime} \mathrm{m}<0,8$ - unfavorable conditions for dispersion

Wind direction also plays a considerable role in contaminants transfer in the atmosphere surface layers. We analyzed winds repeatability from May to September, 2006-2016 and detected that northwest winds prevail in July, and west winds, in May, June, August, and September (Figure 4).

Table 2 contains data on mutual influences exerted by air flows in various Kazan districts depending on wind direction.

Table 1

Number of days when meteorological conditions were unfavorable for admixtures dispersion in the atmosphere and foggy days in Kazan over 2006-2016

\begin{tabular}{|c|c|c|c|c|c|c|c|c|c|c|c|}
\hline \multirow{2}{*}{\begin{tabular}{c} 
Number of days \\
\cline { 2 - 11 }
\end{tabular}} & 2006 & 2007 & 2008 & 2009 & 2010 & 2011 & 2012 & 2013 & 2014 & 2015 & 2016 \\
\hline $\begin{array}{c}\text { Unfavorable for hazardous substances dis- } \\
\text { persion }\end{array}$ & 71 & 127 & 129 & 99 & 81 & 58 & 114 & 97 & 118 & 122 & 90 \\
\hline Foggy & 24 & 29 & 8 & 12 & 12 & 15 & 12 & 17 & 19 & 14 & 16 \\
\hline
\end{tabular}




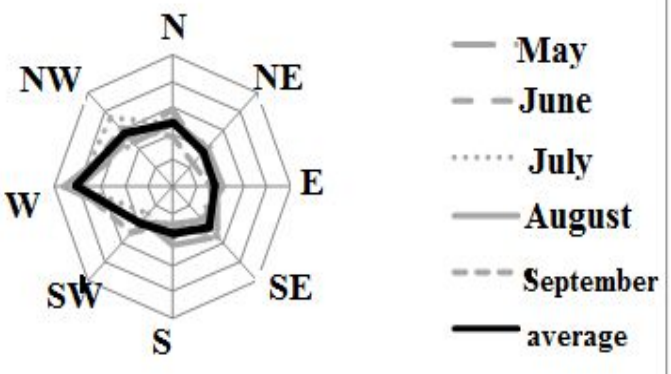

Figure 4. Wind rose in Kazan from May to September, 2006-2016

As we can see from Table 2, contaminants can be transferred from Aviastroitelniy, Bakhitovskiy, Moskovskiy, Kirovskiy, and Privolzhskiy districts territory when north-west and west winds prevail. West winds repeatability from May to September amounted to $24.6 \%$, and northwest winds, $16.6 \%$. When winds blew in other directions relative to industrial enterprises and sport objects locations, contaminants were detected in the air above openair sport facilities..

Conclusions. So, natural-climatic properties in Kazan are responsible for peculiar chemical structure of the atmospheric air in the city. The atmosphere above sport objects is polluted due to contamination sources which are located in the same administrative districts as open-air sport facilities and also due to contaminants transfer from the neighboring districts. Our analysis proves it is necessary to perform further examinations of environmental quality on areas where sport objects are located in a large industrial center. Besides, all the accumulated data should be applied in:

- planning air monitoring during periods when sport events are held;

- organizing work of priority enterprises during periods when meteorological conditions are unfavorable in order to minimize health risks for mass sport events participants and guests;

- making changes into architectural and design plans on the city territory including transport routes development;

- further development and implementation of environmental protection measures at industrial enterprises in the city as Kazan strives to provide healthy life-style for its population and hopes to welcome both Russian and international sport events on its territory.

Table 2

Mutual influences exerted by Kazan districts on each other depending on wind directions

\begin{tabular}{|c|c|c|c|c|c|}
\hline $\begin{array}{c}\text { Contaminated dis- } \\
\text { tricts }\end{array}$ & \multicolumn{5}{|c|}{ Contaminating disricts } \\
\cline { 2 - 6 } Aviastroitelniy & $\begin{array}{c}\text { Aviastroitelniy } \\
\text { N, NE, E, ES, } \\
\text { S, SW, W, NW }\end{array}$ & Vakhitovskiy & Moskovskiy & Kirovskiy & Privolzhskiy \\
\hline Vakhitovskiy & N, NE, NW & $\begin{array}{c}\text { N, NE, E, SE, } \\
\text { S, SW, W, NW }\end{array}$ & S , SW & SE, S, SW & S, SW \\
\hline Sovetskiy & $\mathbf{N W}$ & SW, W, NW & $\mathbf{W}, \mathbf{N W}$ & S, NW & SE, S, SW \\
\hline Novo-Savinovskiy & N, NE, NW & SE, S, SW & W, NW & SW, W, NW & SE, S, SW \\
\hline Moskovskiy & E, SE & NE, E, SE & $\begin{array}{c}\text { N, NE, E, SE, } \\
\text { S, SW, W, NW }\end{array}$ & SE, S, SW & SE, S \\
\hline Kirovskiy & N, NE, E & E, SE & N, SE, E, NW & $\begin{array}{c}\text { N, NE, E, SE, } \\
\text { S, SW, W, NW }\end{array}$ & SE, S \\
\hline Privolzhskiy & N, NW & N, NE, NW & N, NW & N, NW & $\begin{array}{c}\text { N, NE, E, SE, } \\
\text { SW, SW, N, NW }\end{array}$ \\
\hline
\end{tabular}

Note: ${ }^{*}$ means wind directions prevailing in Kazan from May to September; means winds, which carry potentially contaminated air masses. 


\section{References}

1. Bondin V.I. Dvigatel'naya aktivnost' i zdorov'e cheloveka v usloviyakh tekhnogennogo zagryazneniya okruzhayushchei sredy [Human motor activity and health under technogenic environmental contamination]. Fizicheskaya kul'tura, sport, zdorov'e i dolgoletie: Sbornik materialov pyatoi Vserossiiskoi s mezhdunarodnym uchastiem nauchnoi konferentsii [Physical culture, sport, health and longevity: Collection of materials issued for the Fifth Russian scientific conference with international participation]. Moscow, 2016, pp. 3-7 (in Russian).

2. Naskalov V.M. Uchet sostoyaniya atmosfernogo vozdukha dlya organizatsii zanyatii fizicheskimi uprazhneniyami [Accounting of the condition of atmospheric air for the organization of occupations by physical exercises]. Uchenye zapiski universiteta im. P.F. Lesgafta, 2015, vol. 120, no. 2, pp. 95-99 (in Russian).

3. Carlisle A.J., Sharp N.C. Exercise and outdoor ambient air pollution. Br. J. Sports. Med., 2001, vol. 35, no. 4, pp. 214-222.

4. Donnelly A.A, MacIntyre T.E, O'Sullivan N., Warrington G., Harrison A.J., Igou E.R., Jones M., Gidlow C., Brick N., Lahart I., Cloak R., Lane A.M. Environmental Influences on Elite Sport Athletes Well Being: From Gold, Silver, and Bronze to Blue Green and Gold. Front Psychol., 2016, vol. 4, no. 7, pp. 1167. DOI: 10.3389/fpsyg.2016.01167

5. Kargarfard M., Shariat A., Shaw B.S., Shaw I., Lam E.T., Kheiri A., Eatemadyboroujeni A., Tamrin S.B. Effects of polluted air on cardiovascular and hematological parameters after progressive maximal aerobic exercise. Lung, 2015, vol. 193, no. 2, pp. 275-281. DOI: 10.1007/s00408-014-9679-1

6. Zaitseva N.V., May I.V., Kleyn S.V., Vekovshinina S.A., Balashov S.Yu. Prakticheskii opyt otsenki i upravleniya neinfektsionnymi riskami dlya zdorov'ya pri podgotovke massovykh sportivnykh meropriyatii (na primere Vsemirnoi Letnei Universiady - $2013 \mathrm{v}$ Kazani i Olimpiiskikh zimnikh igr - 2014 v Sochi) [Practical experience in the assessment and management of non- infectious health risks during the preparation of the mass sports events (using the example of the 2013 summer Universiade in Kazan and the 2014 winter Olympics in Sochi)]. Zdorov'e naseleniya i sreda obitaniya, 2015, no. 12 (273), pp. 4-7 (in Russian).

7. Kozlovskii A.P., Kalinkin L.A., Bobkov G.A., Morozov V.N. Ekologiya leta 2010 goda i trenirovochnyi protsess $\mathrm{v}$ Podmoskov'e sportsmenov raznykh spetsializatsii [Ecology during summer 2010 and training for sportsmen with different specializations on the Moscow Metropolitan Area]. Fizicheskaya kul'tura $i$ massovyi sport $v$ osnove zdorov'esberegayushchikh tekhnologii, rol' nauki $v$ povyshenii effektivnosti upravleniya podgotovkoi sportsmenov na mnogoletnikh etapakh: Itogovyi sbornik Vserossiiskoi nauchno-prakticheskoi konferentsii s mezhdunarodnym uchastiem [Physical culture and mass sport as a basis for health-preserving technologies, a role science plays in raising efficiency of sportsmen training management for long-term periods: Resulting collection of Russian theoretical and practical conference withinternaitonal participation]. Moscow, 2013, pp. 125-130 (in Russian).

8. Lippi G., Guidi G.C., Maffulli N. Air pollution and sports performance in Beijing. Int. J. Sports. Med., 2008, vol. 29, no. 8, pp. 696-698. DOI: 10.1055/s-2008-1038684

9. Davletova N.Kh. Avtotransport kak global'nyi istochnik zagryazneniya atmosfernogo vozdukha [Autotransport as the main source of the air polution]. Sovremennye naukoemkie tekhnologii, 2005, no. 4, pp. 90 (in Russian).

10. Arkhiv pogody g. Kazan [Weather in Kazan: archive]. Available at: https://rp5.ru (26.09.2017) (in Russian).

11. Ezhegodnyi obzor sostoyaniya zagryazneniya atmosfernogo vozdukha [Annual review on atmospheric air contamination]. Available at: http://www.tatarmeteo.ru/ru/monitoring- 
okruzhayushhej-sredyi/ezhegodnyij-obzor-sostoyaniya-zagryazneniya-atmosfernogovozduxa.html (26.09.2017) (in Russian).

12. Selegei T.S., Filonenko N.N., Lenkovskaya T.N. O metodike opredeleniya meteorologicheskogo potentsiala zagryazneniya atmosfery [On the method of determining meteorological air pollution potential]. Optika atmosfery $i$ okeana, 2015, vol. 28, no. 8, pp. 725-729 (in Russian).

13. Tafeeva E.A., Ivanov A.V., Titova A.A., Akhmetzyanova I.F. Monitoring zagryazneniya atmosfernogo vozdukha kak faktora riska zdorov'yu naseleniya Kazani [Air pollutions as a risk factor for the population health in Kazan city]. Gigiena i sanitariya, 2015, no. 3, pp. 37-40 (in Russian).

14. Yanglicheva Yu.R., Valeeva G.R. Zakonomernosti formirovaniya khimicheskogo sostava atmosfery na territorii g. Kazan' [Laws of formation of chemical composition of the atmosphere in the territory of Kazan]. Yug Rossii: ekologiya, razvitie, 2016, no. 2, pp. 108-120 (in Russian).

15. Azarov V.N., Dontsova T.V. O balansakh vrednykh veshchestv v atmosfere krupnykh gorodov [Balances of pollutants in the atmosphere of largest cities]. Internet-vestnik VolgGASU, 2014, no. 1, pp. 1-11. Available at: http://vestnik.vgasu.ru/? source $=4 \&$ articleno $=1538$ (01.10.2017) (in Russian).

16. Rybkin V.S., Chuikov Yu.S., Kolomin V.V., Teplaya G.A., Vavilina A.V. Ekologicheskie problemy i sostoyanie zdorov'ya naseleniya v Astrakhanskom regione [Environmental Problems and health status in Astrakhan Region]. Astrakhanskii vestnik ekologicheskogo obrazovaniya, 2016, no. 1, pp. 36-41 (in Russian).

Davletova N.Kh., Tafeeva E.A. Influence exerted by natural-climatic conditions on air quality on areas where open-air sport facilities are located (on the example of Kazan). Health Risk Analysis, 2018, no. 1, pp. 39-46. DOI: 10.21668/health.risk/2018.1.05.eng

Received: 17.01 .2018

Accepted: 23.03.2018

Published: 30.03 .2018 